UDK 528.92

\title{
DEVELOPMENT OF 3D CITY MODEL APPLYING CADASTRAL INFORMATION
}

\author{
Rytė Žiūriené ${ }^{1}$, Rimantė Mešliūté ${ }^{2}$ Daiva Makutẻniené $\dot{3}^{3}$ \\ Dept of Graphical Systems, Vilnius Gediminas Technical University, Sauletekio al. 11, LT-10233 Vilnius, Lithuania \\ ${ }^{1}$ E-mail: Ryte.Ziuriene@fm.vtu.lt \\ ${ }^{2}$ E-mail: voverka@yahoo.com \\ ${ }^{3}$ E-mail:delta@fm.vtu.lt
}

Received 2212 2005, accepted 10042006

\begin{abstract}
Problems of development of 3D city models are analysed. To develop such kind of model a great amount of information has to be computed. Collecting and matching the initial data is the most time and labour consuming job. Therefore first of all we have tried to investigate such a data source that would comprise the biggest part of needed data. We also have been looking for the data source that enabled us to constantly refresh and present the data describing the real or true to life situation. We have analysed the possibilities of city cadastral information system and here we state that it is suitable for that purpose. This article presents the idea how 3D city model consisting of prismatic building block models could be developed with the help of available cadastral information.
\end{abstract}

Keywords: 3D city model, cadastral information, visualisation, modelling.

\section{Introduction}

The demand for 3D (three dimensional) city models is growing within various fields, namely, urban planning and design, architecture, environmental visualisation and many others [1]. The efficient generation of the 3D city models is improving the practice of urban environmental planning and design. Together with the development of new technologies there appears the need for applying 3D model instead of 2D model. The 3D model gives us the opportunity for a better and more comprehensive data evaluation. In the $3 \mathrm{D}$ city model the presentation of a particular situation is easier to execute as well as it is more informative; besides, the computer-aided spatial analysis becomes possible to be carried out. Spatial city model is necessary for scientists in cases when noise, heat, flood or fire spreading in cities is to be simulated. Telecommunication companies require $3 \mathrm{D}$ data in order to be able to calculate wave propagation in urban environment.

Development of 3D city model requires appropriate data. 3D data model requires the following data terrain data, data on buildings with facades and roofs, roads, parks, traffic signs, trees etc. Most of the data is stored in the existing databases, DTM's (Digital Terrain Model), information could be received from the aerial images, but some of the data is not comprehensive enough. However, realistic vizualisation mainly depends on data accuracy and completeness.

When developing 3D city model, it is very important to define the objectives and targets for which this model is being created and tasks to be carried out with the help of the model. The reconstruction of urban areas is still a rather complex process involving quite a lot of time and manual interactions. Several different methods are applied to provide appropriate accuracy data and resolution as well as to obtain the $3 \mathrm{D}$ topology $[2,3]$. The utilised methods can be subdivided into three major groups: manual, semi-automatic and automatic.

This article presents 3D city model, which uses automatic method and which consists of prismatic building block models. With the help of this model we can visualise objects of the city in scale 1:500, 1:1000, also execute particular spatial analysis. Block extrusion is a fusion of 2D building footprints with airborne survey data and other height resources. GIS (Geographic Information System) technology allows to overlay 2D maps on airborne data and determine the spatial characteristics of the image within each building footprint. They lack architectural detail and they convey no compelling sense of the environment but are sufficient for analysing the view sheds and the shortest path.

\section{Applications for 3D Urban Models}

Few different categories of usage could be applied dealing with $3 \mathrm{D}$ city models. They could be defined as the following [4]: (1) planning and design, (2) infrastructure and facility services, (3) commercial sector and marketing, (4) promotion and learning of information on cities.

(1) Planning and Design. Planning and detailed design reviews problems of site location, community planning and public participation. They all require 3D 
visualisation, because it is the best way how to supply the information on the analysed object in the best appropriate way. The focus is upon aesthetic considerations of landscapes as well as daylight and line-of-sight. Visual representation of environmental impact is also widely supported by 3D models [5]. This concerns various kinds of hazards to be visualised and planned for, and the ways of visualising the impact of future disasters as well as local pollutants at a fine scale.

(2) Infrastructures and Facility Services. Urban infrastructure such as water, sewerage, and electricity provision as well as road and rail network - all require detailed 2D and 3D data for their improvement and maintenance. The analysis of sight-lines for mobile and fixed communications is also crucial in the environments dominated by high buildings in order to secure a clear reception of signals. Finally, analysis and visualisation of access routes to various locations by police, fire, ambulance and other emergency services are significant for maintaining a safe environment.

(3) Commercial Sector and Marketing. 2D and 3D models are effective for visualising the locations of cognate uses, spatial distribution of the clients and market demands for specific economic activities as well as the availability of space for development. They also enable the computation of detailed data concerning floor-space and land availability as well as land values and costs of development. Finally, virtual city models in 2D and 3D provide portals to virtual commerce through semirealistic entries to remote trading and other commercial domains.

(4) Promotion and Learning of Information on Cities. 3D visualisation offers entries to urban information hubs where users at different levels of education can learn about the city as well as to give access to other learning resources through the metaphor of the city. In particular, it provides methods for displaying the tourist attractions of cities as well as ways in which tourists and other newcomers can learn about the geography of the city.

\section{Analysis of existing 3D city models}

3D city model is created in the following stages: starting with collecting initial data, finishing with visualisation of the compiled model. Alongside with the progress of technology, different ways of model development have been investigated. Below there are presented some of them, which correspond to the task solved in this paper.

In order to develop $3 \mathrm{D}$ city model first of all we need to have data source, which depends on chosen methods and results.

1. Data source. The main data source is very often considered to be material data, namely topographic maps, 2D digital maps, 2.5D digital maps, aerial photographs, ortophoto (aerial) images, terrain data or laser profiler data. Each of these sources store different amount and type of data. A data source depends on the purpose the 3D city model has been created for, the precision of created model etc.
2. Software. Software depends on how we create 3D city model - do we collect and process data with the existing programmes or collect data and process it with newly created programmes. For example, in Map Cube 3D city model [6] was created using Data Loading Program, Database Operating system and Data Output program. In Shah Alam Virtual City (SAVC) [7] were used ArcGIS, 3d Studio Max, Cosmo player etc. And in 3D city model of the central part Vilnius city [8] there were used ArcInfo 8.3 $3^{\mathrm{TM}}$ and 3D Analyst programs.

3. Modelling approach. This approach has got several targets: input data (topographic maps, 2D digital maps, aerial photographs etc), methods (how do we get particular elements of 3D city model), output data (final model). For example, in Besictas Region 3D city model [9].

4. Visualisation. In order to achieve the highest form of visualisation, VR technology could be used. This technology is applied for 3D city viewing and processing purposes in real time. For example, Shah Alam Virtual City (SAVC) [7] the refinement process of the virtual 3D city model is done in Virtual Reality Markup Language (VRML). VRML is the ISO standard to display 3D data in the web. In MapCub3D city model [6] was created VR viewer called Urban Viewer. With the help of this viewer it's better to deal with a great amount of 3D city data, easier to operate with the data as well as draw faster.

\section{Structure of cadastral database}

In order to create 3D city model, we need appropriate data. In this paper, cadastral data from cadastral data base were used to create 3D city model. This data is stored by SE Centre of Registers. We use this data because there has been created a good informational system in which the data are well structured, systematised. These data are always renewed and corrected and will always reflect the existing situation. Data submitted in this DB are precise as the information is judicially certified and registered in real estate registry as real estate cadastral data

We can chart data in real estate data base as follows (Fig 1).

A real estate cadastre is a set of organically and systematically ordered graphic and attributive data of immovable objects (in the national coordinate system), stored in computerised version. The data could be used individually on line or in any other way [10].

A real estate cadastral map comprises a graphic part of real estate cadastral which exhibits the place of immovable objects and its boundaries in the national coordinate system. This information is given in numbers and graphical elements.

A real estate cadastral map is worked out and corrected with the help of geo-reference DB, real estate registry data, documents compiled during the process of immovable objects formation and preparation. 
The cadastral map embraces all the territory of the Republic of Lithuania. It consists of the following layers.

\begin{tabular}{|c|c|}
\hline \multicolumn{2}{|c|}{ Real estate cadastre database } \\
\hline $\begin{array}{l}\text { Real estate cadastre } \\
\qquad \text { data } \\
\text { - Identification data of } \\
\text { real estate } \\
\text { - Real estate quality } \\
\text { and quantity } \\
\text { characteristics } \\
\text { - Primary objective } \\
\text { purpose of real estate } \\
\text { usage }\end{array}$ & $\begin{array}{l}\text { Real estate cadastral } \\
\qquad \text { map } \\
\text { Graphic data about } \\
\text { registered } \\
\text { boundaries of real } \\
\text { estate objects, their } \\
\text { position and } \\
\text { location in national } \\
\text { coordinate system }\end{array}$ \\
\hline $\begin{array}{l}\text { Data from geo-reference } \\
\text { database CDB10LT } \\
\text { (Cadastral Data Base } 10 \\
\text { LT): } \\
\text { - Geo-reference base } \\
\text { - Boundaries of localities } \\
\text { (neighbourhood, towns) } \\
\text { - Vegetation (trees, etc) } \\
\text { - Axial street lines } \\
\text { - Etc }\end{array}$ & $\begin{array}{l}\text { MC (SI) ,Vilnius city } \\
\text { plan“ geographic data } \\
\text { of Vilnius city } \\
\text { - Structure layout } \\
\text { - Address points } \\
\text { - Axial street lines } \\
\text { - Etc }\end{array}$ \\
\hline
\end{tabular}

Fig 1. The chart of data in Real estate cadastre database

The real estate cadastral map is used for works related to territory planning, land cadastre projects implementation, for other cadastres and registries helping to determine real estate taxation and for other purpose [11].

When registering the real estate cadastral data into the National Real Estate Cadastre, the latter items are identified onto the real estate cadastral map. Before designation of real estate boundaries on the real estate cadastral map, the re-examination is executed to verify the layouts of the immovable things to be sure that the schemes have been properly formulated and positioned and to be able to detect as well as determine any real estate item in the territory of the Republic of Lithuania according to the applied data of the national coordinate system

There has been compiled a general computerised system to administer real estate property in Lithuania. This system incorporates attributive and graphical data on the parcels (cadastral data), ownership rights, restrictions and obligations of real estate usage, data on the structures themselves, apartments, engineering structures etc.

One of the constituent parts of cadastral information system of the National Land Cadastre is considered to be the graphical data on parcel boundaries, indicating buildings located on the parcels and submitting other required data. Before any parcel registration to be performed at the National Registry Centre, the parcels are plotted onto the cadastre map as well as their size and geographic position is checked in regard to other parcels.

Graphical information is necessary in order to register a real estate item as well as one's rights of ownership to the item itself, to ensure the correctness and precision of the real estate registry data, to characterise the geographic location of registered parcel on the map and to plot it geometrically in respect to the neighbouring parcels.

\section{Development of 3D city model}

In order to realise representation of 3D model, foremost we need to describe its composition, ie to create the system of representation of city model graphical elements (Fig 2). During a long-lasting development of cartography, the system of graphical elements has been elaborated and it contains structures, water system, road net, certain region boundaries, terrain surface, vegetation etc. The author has made an attempt to prove that those elements have to be considered as the essential ones and the proper presentation of city model has served for that purpose [12]. The main elements the visualisation of which is under consideration at this stage of investigation are to be regarded as terrain surface and buildings. Besides those two elements, other objects such as separate trees, streets, vegetation areas etc could be added to fully accomplish city model visualisation.

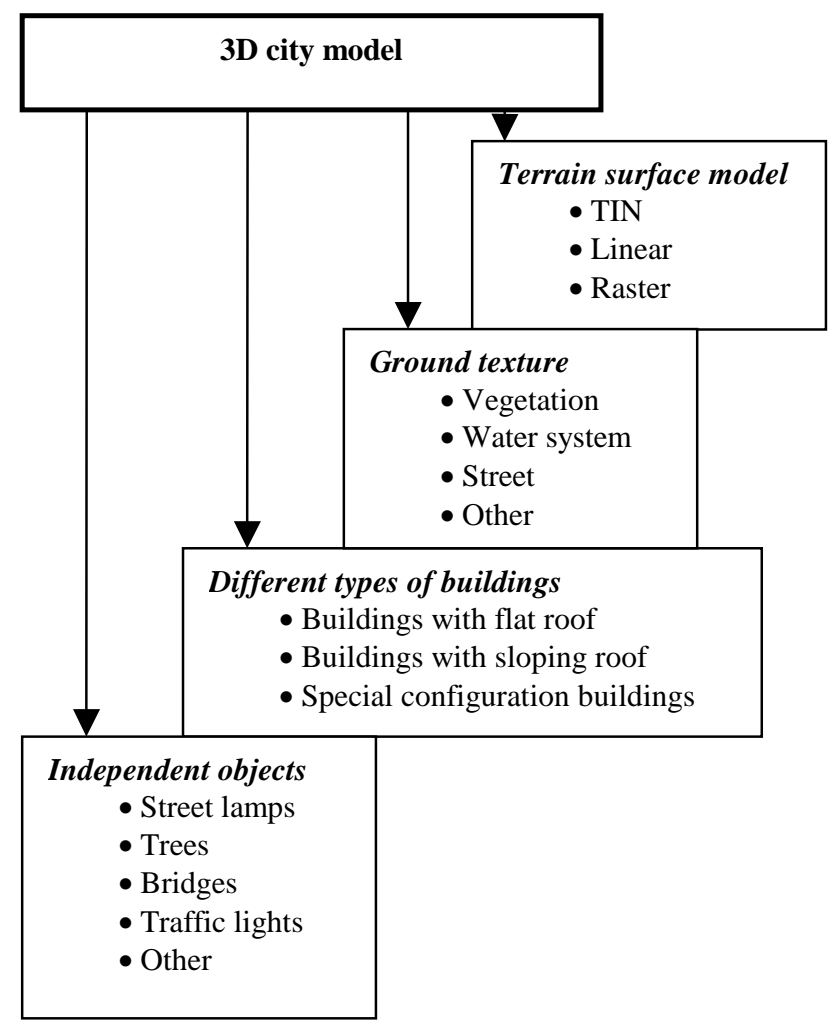

Fig 2. The chart of graphical elements of the city 


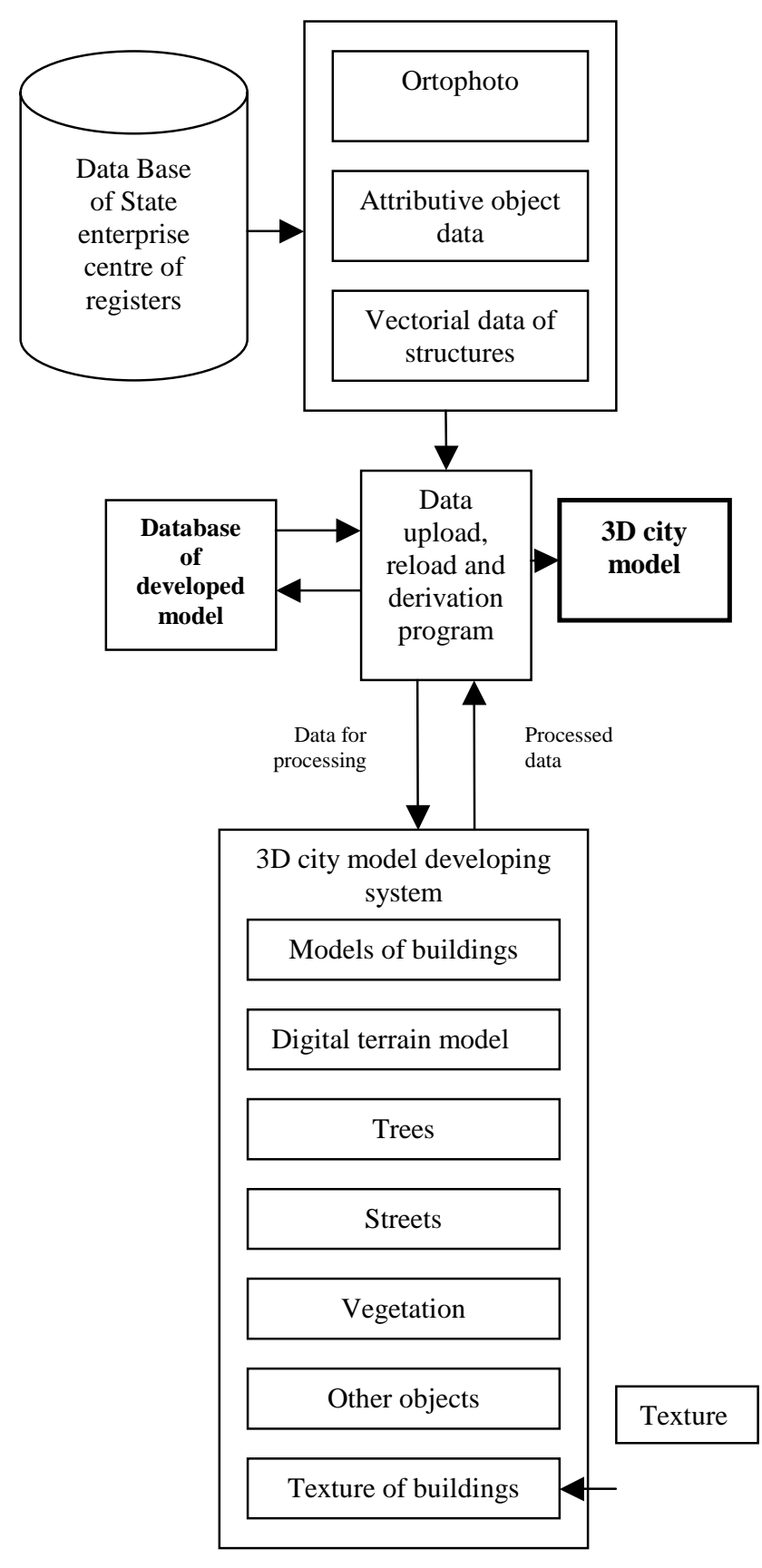

Fig 3. A scheme of application of cadastral data in 3D city model development

In executing urban planning and object visualisation within an appropriate scale suitability of the data received from CDB the terrain surface, buildings and other objects are considered sufficient for visualisation. The scheme in Fig 3 shows what object data could be received from Data Base of Governmental Centre of Registers and how the data could be used for development of 3D city.

\section{Implementation}

According to the scheme of data circulation (Fig 3), program D3DCM (Development of 3D City Model) has been created, which enables the generation of digital terrain surface and modelling of buildings applying cadastral information. D3DCM works as an extension of Autodesk Map® 3D 2005 program. This program has been chosen for 3D city visualisation, because it is a good tool for integration of CAD and GIS technologies. Autodesk Map® 3D 2005 supports the environment of MS Visual Basic $®$ language for programming and editing. This language in integration with Microsoft Office Access ${ }^{\circledR} 2003$ database has been used in creating D3DCM program. The D3DCM program enables the integration of data received from the National Registry Centre (this data is presented using ArcView® 8.2 program), and from CDB10LT (Cadastral Data Base 10LT) (data presented using ArcInfo® program).

D3DCM program applies continuously the renewed and judicially approved data received directly from the National Registry Centre and CDB10LT, that is why they reflect the real situation concerning the real estate. These data are accumulated in one place and that is why the data are harmonised; besides, these data are enough for developing the model of the selected detailed city 3D.

The National Registry Centre does not collect and store information on altitude points available for digital terrain surface generation. Since all data are received from CDB10LT, the data on the terrain surface altitude points have to be stored in the same place. They are stored in one of the layers of ArcInfo®. These layers, together with the information possessed on them, are transferred in the form of $*$.xml file.

The buildings are visualised using extrude operation, when footprint perimeter is extruded through the proper altitude. Each building has its centroid, which has unique ID. In database table for each ID there is attached perimeter, area, $\mathrm{z}$ value, address and the number of floors. According to these parameters D3DCM program selects discrepancies between the drawing and data base recordings, recognises buildings as objects and makes it necessary to visualise the buildings $3 \mathrm{D}$. The value of altitude is received from the database. Digital terrain surface model is generated in accordance with the chosen type version (linear-horizontal, TIN). Both objects are generated automatically, determining data base for building visualisation, and digital terrain surface model is generated by inserting the file containing altitude information and by selecting the desirable surface visualisation type.

D3DCM acts under such a principle. First of all, the vector data are imported from the National Register Center using ArcView (B 8.2 program. These data are stored in different shapefile layers. The geometry for a feature is stored as a shape comprising a set of vector coordinates. For creating 3D city model with D3DCM program we have to import essential layers with building perimeters and centroids of those perimeters. The layers with parameters of buildings and centroids of buildings are imported to Autodesk Map® 3D 2005 program and so creating in it *.dwg type drawing with the corresponding layers (Fig 4). 


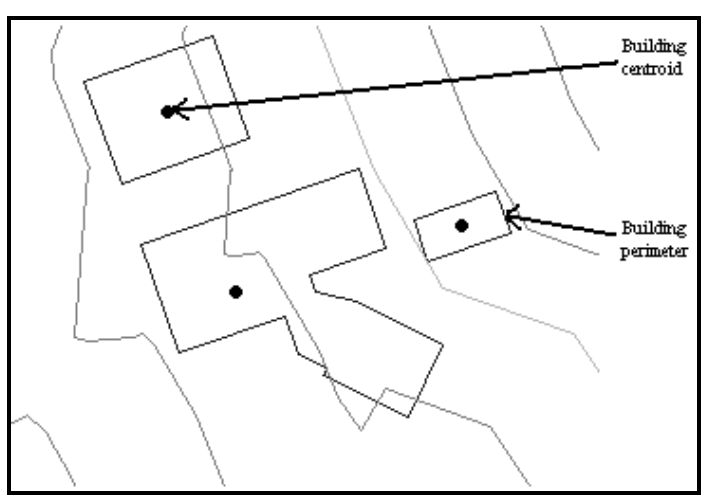

Fig 4. A fragment of *.dwg drawing with buildings perimeters and buildings centroids

Then the data from National Register Center's Oracle ${ }^{\circledR}$ database are imported to the Microsoft Office Access ${ }^{\circledR} 2003$ program which is also used by D3DCM program. In this case the data include parcel centroid ID (Fig 5), parcel area, parcel perimeter, altitude value $\mathrm{z}$ and other additional data (address of building, building type, floor quantity, year of construction etc). The three first data are required for the altitude extrusion of buildings. There might be supplied more data in accordance with the possessed data stored in database, the aim of the model compiled and the needs of the user.

\begin{tabular}{|r|r|r|r|r|r|l|}
\hline ID & AREA & PERIMETER & Z & LINKS_QTY & Adresas & Aukst_Sk \\
\hline 1 & 620.196 & 99.623 & 12 & 1 R.Jankausko 15 & 3 \\
\hline 2 & 1037.69 & 130.485 & 14 & 1 R.Jankausko 16 & 11 \\
\hline 3 & 870.006 & 118.971 & 23 & 1 R.Jankausko 17 & 12 \\
\hline 4 & 1296.61 & 144.28 & 33 & 1 R.Jankausko 18 & 12 \\
\hline 5 & 822.171 & 115.643 & 12 & 1 R.Jankausko 19 & 9 \\
\hline 6 & 624.917 & 101.999 & 10 & 1 R.Jankausko 20 & 5 \\
\hline
\end{tabular}

Fig 5. The table of buildings database

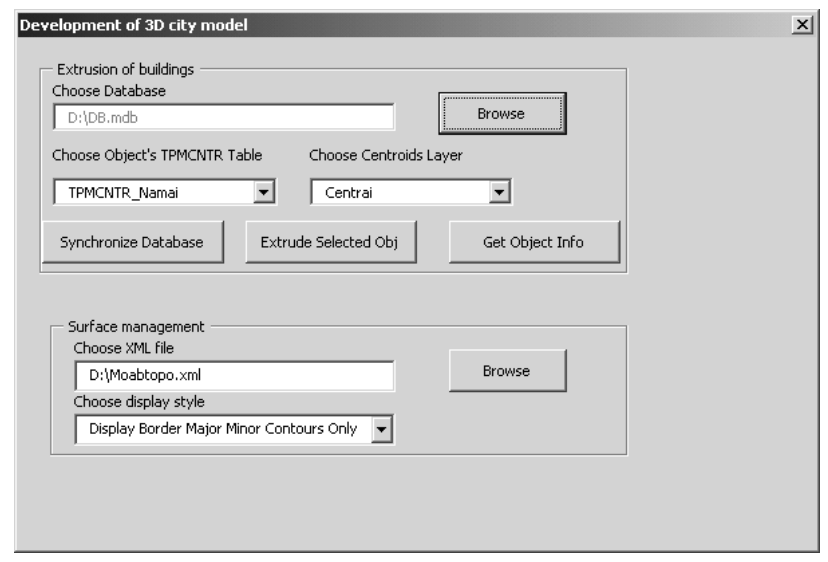

Fig 6. A dialog box of 3D city model development

There is presented a dialog box of 3D city in Fig 6 model development. The dialog box consists of two parts: Extrusion of buildings (for buildings vizualisation) and Surface management (for terrain surface visualisation). In order to visualise buildings firstly it is needed to indicate the data base from which the data are going to be chosen on buildings (Choose Database), then to choose the layer of the drawing, in which there are the centroids of buildings and then to synchronise the data base
(Synchronise Database), ie to check if the data on the drawing correspond to the data of the table. Then it becomes possible to extrude the selected object (Extrude Selected $\mathrm{Obj}$ ) or obtain information on the chosen object. For the visualisation of the terrain surface there is selected .xml file (Choose XML File) and the type of the chosen display style (Choose Display Style).

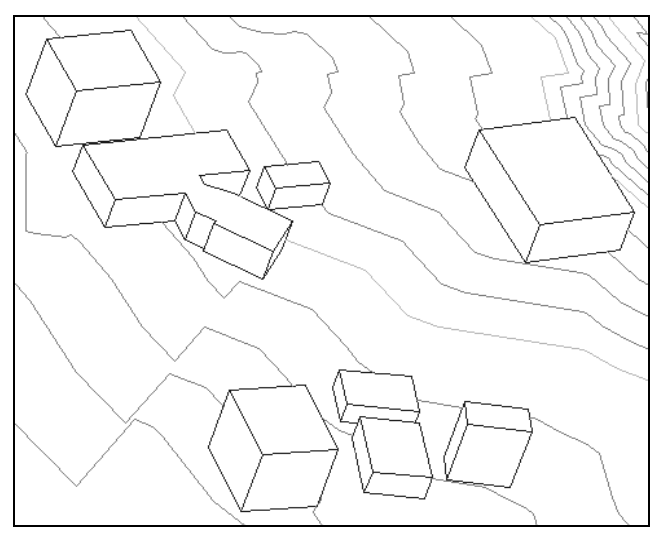

Fig 7. 3D city model presented in linear-horizontal terrain surface display style

D3DCM program automatically generates terrain surface and buildings (Fig 7). While continuing the implementation of this 3D city model, such objects as separate trees, vegetation areas, bridges and streets have to be added. Visualisation of these objects, taking into consideration their peculiarities, is available in accordance with the analogous way provided with the building vizualisation.

\section{Conclusions}

After having analysed the structure of cadastral data it is possible to conclude, that this system shall have to be applicable for development of any selected 3D city model, because it has the appropriate initial data, namely orthophoto, vector data (footprint perimeters of buildings), point data (altitude points of terrain surface, location points of trees). The data are presented in an applicable form, because a similar information is grouped into appropriate layers. Data from one layer use the same table of attributive database. Data are stored in one place. The implication is that we do not waste time for data collecting from various institutions to match it. Moreover, there is an additional advantage for this database usage, namely the feature of regular data renewal. The data do not indicate a designed situation, but the real or true to life situation, because in this database itself there is stored only the precise information judicially authorised and registered under the real estate registry as authentic real estate cadastral data

There has been created an algorithm on the experience in modelling 3D city models as well as on the bases of cadastral information system analysis. This algorithm enables the automation of the main stages of model development, in accordance with reliable and constantly renewable initial data. 
There was created a D3DCM program, which enables automatically generate 3D terrain surface and buildings. There have been determined possibilities not only for the visualisation of those objects, but for providing certain analysis of the model, which is inevitably required within the urban planning process.

There is a possibility to read a more detailed information about ideas presented in the paper and its realisation in one of co-authors R. Mešliūtė Master degree thesis [13].

\section{References}

1. Zlatanova, S. 3D GIS for urban development, 2000, $\mathrm{PhD}$ thesis, ISBN 90-6164-178-0, ITC publication 69, ISBN 90-6164-178-0.

2. Zlatanova, S. 3D modelling for augmented reality. In: Proc of the 3rd ISPRS Workshop on Dynamic and MultiDimensional GIS, 23-25 May, 2001, Bangkok, Thailand, p. $415-420$.

3. Vermeij, M.; Zlatanova, S. Semi-automatic 3D building reconstruction using Softplotter. In: Proc of the International Symposium on "Geodetic, Photogrammetric and Satellite technologies: development and integrated applications", 8-9 Nov 2001, Sofia, Bulgaria, p. 305314.

4. Shiode, N. 3D urban models: recent developments in the digital modelling of urban environments in threedimensions. GeoJournal, 52 (3), 2001, p. 263-269.

5. Tsou, J.-Y.; Chow, B.; Lam, S. Performance-based simulation for the planning and design of hyper-dense urban habitation. Automation in Construction, Vol 12, 2003, p. 521-526.

6. Takase, Y.; Sho, N.; Sone, A.; Shimiya, K. Automatic generation of $3 \mathrm{D}$ city models and related applications. International Archives of the Photogrammetry, Remote Sensing and Spatial Information Sciences, Vol XXXIV5/W10, 2003 [žiūrèta 200503 25]. Prieiga per internetą: <http://www.photogrammetry.ethz.ch/tarasp_workshop/pa pers/takase.pdf>

7. Eran Sadek Said, B.; Md Sadek, Sayed Jamaludin, B. S. Ali; Mohd. Rosdi B. Md. Kadzim. The Design and Development of a Virtual 3D City Model. 2005 [žiūrèta 200504 17]. Prieiga per interneta: $<$ http://www.malaysiagis.com/gis_in_malaysia/articles/arti cle47.pdf $>$

8. Čypas, K. Preparation of 3D digital city model development technology based on geoinformation systems. Geodesy and Cartography, Vol XXIX, No 3. Vilnius: Technika, 2003, p. 90-97.

9. Emem, O.; Batuk, F. Generating precise and accurate 3D city models using photogrammetric data. YTU, Division of Photogrammetry and Remote Sensing, Besiktas Istanbul, Turkey. 2004 [žiūrèta 200503 25]. Prieiga per internetą: <http://www.isprs.org/istanbul2004/comm4/papers/386.pdf>

10. LR Nekilnojamojo turto kadastro istatymo pakeitimo istatymas. 2003 m. gegužès 27 d. Nr. IX-1582. Valstybès žinios, 2003, Nr. 57-2530. Isigaliojo nuo 2004 m. sausio 01 d. [žiūrèta 200504 05]. Prieiga per internetą: $<$ http://www3.lrs.lt/cgi-

bin/preps2?Condition $1=212612 \&$ Condition $2=>$
11. Activities of the State enterprise „Registrų centras“ [žiūrèta 200503 15]. Prieiga per internetą: <http://www.kada.lt/apie/veikla/nt_gis.php>

12. Chengming, L.; Jizhou, W.; Zongjian, L. Research on three-dimensional abstraction and description of reality. XXth ISPRS Congress, 12-23 July 2004, Istanbul [žiūrèta 200503 25]. Prieiga per internetą: <http://www.isprs. org/istanbul2004/comm4/papers/324.pdf>

13. Mešliūtè, R. Development of $3 \mathrm{D}$ city model applying cadastral information. Master degree thesis. VGTU, Dept of Graphical Systems, 2005 (in Lithuanian).

\section{MIESTO 3D MODELIO KŪRIMAS TAIKANT KADASTRO INFORMACIJA}

\section{R. Žiūrienè, R. Mešliūtė, D. Makutėnienè}

\section{S a n tra k a}

Nagrinejjamos miesto erdvinio modelio kūrimo problemos. Kuriant toki modeli reikia apdoroti labai didelius informacijos kiekius. Daugiausia laiko ir jègu idedama pradiniams duomenims surinkti ir suderinti tarpusavyje. Dèl šios priežasties pirmiausia buvo ieškoma tokio duomenų šaltinio, kuriame jau būtų sukaupta didesnè dalis reikalingu duomenų. Pradinių duomenų šaltiniui buvo keliamas patikimumo reikalavimas. Straipsnyje pateikiama ideja, kaip miesto 3D modelis gali būti kuriamas taikant kadastro informaciją.

Prasminiai žodžiai: miesto 3D modelis, kadastro informacija, vizualizacija, modeliavimas.

Rytė ŽIŪRIENÉ. Dr Dept of Graphical Systems. Vilnius Gediminas Technical University. Sauletekio al. 11, LT-10223 Vilnius-40, Lithuania.

$(\mathrm{Ph}+3705274$ 4848, Fax +370 5274 4844).

Phd (2002). MSc of Informatics (1996), First degree in Architecture (1993). Author (or co-author) of 15 research papers.

Research interests: engineering computer graphics, 3D modelling, CAD systems.

Rimantė MEŠLIŪTĖ. Dept of Graphical Systems. Vilnius Gediminas Technical University. Sauletekio al. 11, LT-10223 Vilnius-40, Lithuania.

$(\mathrm{Ph}+3705274$ 4848, Fax +370 5274 4844).

A graduate of Vilnius Gediminas Technical University (MSc of Informatics 2005, Bachelor of Geodesy 2003).

Research interests: cadastral information system, 3D modelling.

Daiva MAKUTÉnIENĖ. Dr, Assoc Prof. Dept of Graphical Systems. Vilnius Gediminas Technical University. Saulètekio al. 11, LT-10223 Vilnius-40, Lithuania.

$(\mathrm{Ph}+3705274$ 4848, Fax +370 5274 4844).

Phd (2001), MSc of Information technologies (1997), First degree in Architecture (1984), VGTU. Author (or co-author) of 21 research papers.

Research interests: computer aided design systems, intelligent design in computer-aided civil engineering and architecture, information vizualisation technologies. 